DOI: $10.14746 /$ por.2019.1.24

\title{
DYSYDENCI I NOMADOWIE W PAŃSTWACH (NIE TYLKO) POSTTOTALITARNYCH. CZYLI DLACZEGO TYLE PROBLEMÓW, SKORO JEST TAK DOBRZE?
}

\author{
Rafae Pawee WierzchosŁawski ${ }^{1}$ \\ (SWPS Uniwersytet Humanistycznospołeczny)
}

\begin{abstract}
Słowa kluczowe: dysydenci, elity, nomadzi, populizm, liberalna demokracja, transformacja, The Legacies of Totalitarianism, Aviezer Tucker

Keywords: dissidents, elites, nomads, populism, liberal-democracy, transformation, The Legacies of Totalitarianism, Aviezer Tucker
\end{abstract}

\begin{abstract}
Abstrakt: Rafał Paweł Wierzchosławski, DYSYDENCI I NOMADOWIE W PAŃSTWACH (NIE TYLKO) POSTTOTALITARNYCH. CZYLI DLACZEGO TYLE PROBLEMÓW, SKORO JEST TAK DOBRZE? „PORÓWNANIA” 1 (24), 2019. T. XXIV, S. 275-284. ISSN 1733-165X. Książka Aviezera Tuckera The Legacies of Totalitarianism. A Theoretical Framework wpisuje się nurt prac, które podejmują kwestię zwycięstwa liberalnej demokracji w krajach o totalitarnej przeszłości i postsowieckiej dominacji po 1989 roku. W tekście analizuję problemy, które można wskazać w kontekście sugestii autora, że dysydenci (i kategoria życia w prawdzie) odgrywali istotną rolę nie tylko w obaleniu komunizmu (realnego socjalizmu), lecz także pełnią ją w utrzymaniu zdobyczy liberalnej demokracji w krajach Europy Środkowo-Wschodniej, która obecnie ma być zagrożona demonami populizmu, nacjonalizmu, ksenofobii. Zasadnicze pytanie mojego tekstu dotyczy kwestii, czy byli dysydenci potrafili stworzyć dobre i funkcjonalne państwa, czy też nowe elity zdezerterowały, pozostawiając instytucje państwowe na łup pasożytujących na nich nomadów, co prowadzi do sprzeciwu obywateli. Kwestia ta dotyczy, jak się wydaje, nie tylko krajów tego regionu, lecz także całej Europy.
\end{abstract}

Abstract: Rafał Paweł Wierzchosławski, DISSIDENTS AND NOMADS (NOT ONLY) IN POST-TOTALITARIAN COUNTRIES. OR WHY THERE ARE SO MANY PROBLEMS IF EVERYTHING IS FINE. “PORÓWNANIA" 1 (24), 2019. Vol. XXIV, P. 275-284. ISSN 1733-165X. Aviezer Tucker's book The Legacies of Totalitarianism: A Theoretical Framework can be classified among works which

1 E-mail: rafalpawelwie@gmail.com 
settle with the totalitarian past and discuss the issue of the victory of liberal democracy in post-Soviet states after 1989. From the many issues examined in his book, I would like to focus here on the author's interesting intuition that dissidents played an important role not only in the overthrow of communism (real socialism) but also in the preservation of the liberal democracy in Central and Eastern Europe, which, in his view, is now threatened by the demons of populism, nationalism, xenophobia, etc. The essential question is whether dissidents have managed to create such an institutional framework as will protect the society against the temptation of populism, by offering citizens - all social groups - a state with stable, effective structures, respect for individual freedom, and a sense of safety (including social security), or the institutional problems he mentions results from the negligence and desertion of the elites in the first years of the transformation a state of things which has lasted until now?

Książka Aviezera Tuckera The Legacies of Totalitarianism. A Theoretical Framework wpisuje się nurt prac rozliczeniowych, które skupiają się na kwestii zarówno samego totalitaryzmu, jak i jego liberalno-demokratycznego przezwyciężenia w krajach dominacji postsowieckiej po 1989 roku. Warto zaznaczyć, że autor wcześniej opublikował książkę poświęconą politycznej filozofii dysydentów czeskich The Philosophy and Politics of Czech Dissidence from Patočka to Havel oraz że przez wiele lat żył, studiował i pracował w Pradze już po aksamitnej rewolucji.

W tym kontekście chciałbym zwrócić uwagę na ciekawą intuicję autora, który przypisuje dysydentom istotną rolę nie tylko w obaleniu komunizmu (realnego socjalizmu), lecz także w utrzymaniu zdobyczy liberalnej demokracji w krajach Europy Środkowo-Wschodniej, która jego zdaniem zagrożona jest obecnie demonami populizmu, nacjonalizmu, ksenofobii itp. (Tucker 2015)².

W moim tekście ograniczam się do wskazania kilku problemów wymagających dyskusji (rozważenia), które pojawiają się w kontekście tej intuicji.

\section{1.}

Jak pisze autor, postawę dysydenta (w tym i filozofa-dysydenta) wyraża Havlowski postulat „życia w prawdzie” (living in truth). Przyjęcie i społeczna realizacja tego ideału niewątpliwie przyczyniły się do upadku systemów komunistycznych, chociaż zdecydowanie bardziej problematyczne jest stwierdzenie, że była to główna przyczyna rozpadu tych systemów w krajach bloku sowieckiego (Ost 2018). $\mathrm{W}$ postulacie tym kładzie nacisk na znaczenie świadomej postawy jednostki, w której ceni się wolność indywidualną (w sensie negatywnym), rozumianą jako brak ingerencji $w$ zakres wyboru oraz prawne poszanowanie osobistej autonomii. W tym sensie intuicja życia $w$ prawdzie odwołuje się do podstawowych (niezmiennych) potrzeb ludzkich, których nie są w stanie stłumić i wyeliminować żadne kolektyw-

2 Spośród polskich prac na temat upadku komunizmu można wskazać przeglądowy artykuł Krzysztofa Brzechczyna (2008). 
ne przymusy autorytarnych czy totalitarnych reżimów chcących zdominować na trwałe wolne jednostki. Można zatem powiedzieć, że „siła bezsilnych" stanowi pewien inwariant natury ludzkiej, stałą charakterystykę ludzi, którzy nawet jeśli zostaną poddani opresji, będą poszukiwać i prowadzić życie w wolności i prawdzie.

Jeśli zgodzić się z takim odczytaniem, to ma ono istotne (kapitalne) znaczenie dla naszych dalszych rozważań, gdyż w jego świetle można wysunąć hipotezę, że każda groźba domniemanego autorytaryzmu (totalitaryzmu) musi w ostatecznym rozrachunku zderzyć się z genem wolności, którego nie da się wykorzenić i który w dłuższej perspektywie będzie dążył do tego, aby się uzewnętrznić i zrealizować. Tym samym totalitaryzm (przynajmniej w tym kręgu kulturowym) może zaćmić umysły na czas jakiś, ale gen wolności ostatecznie da o sobie znać, uaktywni się i zwycięży.

\section{2.}

Gdy mówimy o genie wolności, mamy na myśli przede wszystkim poziom jednostkowy. Jednakże, jak podkreślają przedstawiciele demokracji konserwatywnej, tacy jak Yoram Hazony (zob. Hazony 2019), ów gen wolności może przejawiać się na poziomie zbiorowości, państwa narodowego (wolne państwo wśród wolnych państw). Takie stanowisko zdaniem wspomnianego badacza unika potencjalnych zarzutów o populizm, gdyż wprowadza się odpowiednie zabezpieczenia wolności indywidualnych, które nie mogą zostać podporządkowane celom zbiorowości. Tym samym wolności jednostkowe (sens negatywny) mogą realizować się również w patriotycznym wymiarze obywatela danego państwa (sens pozytywny). Hazony w swych analizach skupia się przede wszystkim na syjonistycznej wizji współczesnego Izraela i jego relacji do innych państw (tradycja postwestfalska), jednak jego analizy mogą mieć pewne znaczenie dla rozważań Tuckera, ponieważ wskazują na wartość narodowej niezależności i suwerenności w kontekście rozmaitych projektów związków między- i ponad- (trans-) narodowych, które autor wiąże z tradycją imperialną w historii myśli politycznej (Hazony 2018, 2019). Wydaje się, że - biorąc pod uwagę kwestie historycznych zaszłości powojennej dominacji sowieckiej oraz oddawania pewnej części suwerenności na rzecz organizacji ponadnarodowych argumentacja Hazoniego może mieć pewne znaczenie dla określenia równowagi między obydwoma aspektami wolności jednostkowej i narodowej (państwowej).

\section{3.}

Jednakże nie wszyscy badacze ruchów dysydenckich oraz transformacji po komunizmie przyjmują bez zastrzeżeń Havlowską sugestię o specyficznej roli dy- 
sydentów $\mathrm{w}$ procesie wyjścia $\mathrm{z}$ totalitarnego zniewolenia oraz podtrzymania idei wolności. Dla przykładu, znany amerykański badacz David Ost, który wcześniej analizował fenomen opozycji w krajach Europy Środkowo-Wschodniej (Ost 2014) oraz skutki przemian po roku 1989 w kontekście przyjęcia neoliberalnego kursu jako drogi wyjścia z komunizmu (Ost 2005), przeciwstawia ostatnio kategorię życia w prawdzie (jako pasywną i zasadniczo elitarystyczną) obywatelskiemu aktywizmowi (civic activism), który, jego zdaniem, miał przynieść zdecydowanie większe efekty w walce z dominacją komunistyczną (Ost 2018). Ost sugeruje, że w odniesieniu do anonimowych obywateli życie w prawdzie wiązałoby się ze zbyt dużymi kosztami, tym samym mogliby sobie na nie pozwolić jedynie ci, którzy mogliby owe koszty ponosić, na przykład dzięki wsparciu i obronie ze strony mediów zagranicznych.

\section{4.}

Przyczyn zagrożeń można dopatrywać się w argumencie pozorności zmian, do jakich miało dość w procesie transformacji. Przykładem tego typu rozważań mogą być prace badaczki rewolucji solidarnościowej Jadwigi Staniszkis na temat postkomunizmu (1990, 2001). Istotą analiz warszawskiej politolog było pytanie o faktyczny zakres zmiany społecznej, do jakiej zaszło w trakcie przemian 1989 roku, którą dobrze oddaje dictum z Lamparta Giuseppe Tomasi di Lampedusy: „Jeśli chcemy, by wszystko pozostało tak, jak jest, wszystko musi się zmienić" (Se vogliamo che tutto rimanga come è, bisogna che tutto cambi) (di Lampedusa 31). Warto zauważyć, że na problem ten w odniesieniu do krajów postkomunistycznych zwraca też uwagę sam Tucker, pisząc o problemach interpretacyjnych wokół spiskowych teorii transformacji oraz paktów elit (Tucker 2015: 19-23). Niezależnie od tego, czy jesteśmy skłonni podzielać tego typu hipotezy (wyjaśnienia) przedstawione przez autorkę na temat powstania zjawiska kapitalizmu politycznego w wyniku uwłaszczenia nomenklatury, która wykorzystała moment przemian do zdobycia lepszej pozycji w tworzącym się systemie gospodarczym, sądzę, że warto mieć je na uwadze w kontekście oskarżeń o groźbę poddania się autorytarnym tendencjom zawiedzionych niezrealizowanymi obietnicami liberalnej demokracji obywateli (Staniszkis 1990, 2001, zob. także na temat związków między ekonomią i polityką w czasie transformacji: Brzechczyn 2012).

W kontekście reakcji negatywnych (odrzucenia czy też korekty) modelu demokracji liberalnej można chociażby przywołać dyskutowane ostatnio opracowanie zespołu Macieja Gduli Miastko (2017). Nawet jeśli uznać, że Gdula i jego grupa badawcza uchwycili pewne tendencje neoautorytarne w grupie elit polskiej prowincji, które dają wsparcie oskarżanym o takowe tendencje rządom tzw. „dobrej zmiany”, 
to pytanie pozostaje, czy gen wolności został (chwilowo) przytłumiony przez inne wartości z nim konkurujące (na przykład egalitarne, bytowe, itp.).

\section{5.}

W kontekście zróżnicowania ekonomicznego można przywołać jako ilustracje tezy o klęsce Solidarności Osta (2005) analizy amerykańskiej antropolog Elisabeth Dunn, która badała proces prywatyzacji rzeszowskich zakładów Alima, produkujących odżywki dla dzieci, i skutki jego przejęcia przez amerykańską korporację Gerber (Dunn). Prywatyzacja ta miała stanowić symbol udanego przyciągania międzynarodowych inwestycji po 1989 roku oraz modernizacji polskiego przemysłu. Jednak z puntu widzenia doświadczenia indywidualnego w jej wyniku pracownicy $\mathrm{i}$ ich działania $\mathrm{w}$ coraz większym stopniu stawały się abstrakcyjnymi jednostkami wyrażanymi za pomocą wykresów, tabel i rozliczeń księgowych. W kontekście analiz Dunn nasuwa się skojarzenie, że krytyka Osta pojęcia kategorii „życia w prawdzie" może nabierać nowego, posttransformacyjnego znaczenia (Ost 2018). Uprzedmiotowienie i zniewolenie może dotyczyć nie tylko wolności politycznej, lecz także wolności ekonomicznej oraz poczucia godności jednostkowej, która z obydwoma znaczeniami się wiąże. Zarówno Ost, jak i Dunn piszą niewątpliwie z pozycji mocno lewicowych, lecz pewną gorzką ironią wydaje się fakt, że lewicowa antropolog, badając sens poczucia utraty godności pracowniczej w wyniku amerykańskiej kuracji szokowej zastosowanej w przejętym zakładzie pracy, odwołuje się do rozważań antropologiczno-etycznych, a zwłaszcza encykliki Laborem exercens konserwatywnego z jej punktu widzenia papieża Jana Pawła II (Dunn 170-174, zob. także Dunn 125-129 oraz Stawrowski 2010; Krasnodębski 2018).

W perspektywie procesu transformacji można zadać ważne pytanie: jak ma się postulat życia w prawdzie w obliczu uprzedmiatawiających rozwiązań zaproponowanych odgórnie tym, którzy - niekiedy z narażeniem życia - dopominali się podmiotowości w przestrzeni publicznej (w tym i ekonomicznej), łącząc ją zarazem z troską o dobro wspólne. Niewątpliwie rozwiązania te pojawiły się w sytuacji ekonomiczno-politycznego bankructwa dotychczasowego systemu, niemniej jednak zmieniły radykalnie kontekst solidarnej wspólnotowości, która pojawiła się jako zbiorowy wyraz pragnienia „życia w prawdzie” z czasów Solidarności 1980-1981³.

3 W tym kontekście warto przypomnieć republikańską interpretację dziedzictwa Solidarności oraz skutków procesu transformacji, o której pisali: Krasnodębski 2003; Ciżewska 2010. Wspomniani autorzy podjęli również kwestę obecności republikanizmu w myśli dysydenckiej, zob. Krasnodębski 2018; Ciżewska-Martyńska 2020. Na temat problemów z implementacją republikańskiej idei wolności jako braku dominacji we współczesnych państwach zob. Wierzchosławski 2002, 2014. 
6.

W kontekście wspomnianych korekt liberalnej demokracji chciałbym przywołać dwie ostatnio opublikowane książki, pisane z pozycji liberalnych. Autorzy pracują w tym samym ośrodku akademickim, St. Anthony College w Oxfordzie: Thimothy Garton Ash (2018) i Jan Zielonka (2006, 2014, 2018). Obaj byli świadkami i analitykami zachodzących w regionie transformacji systemowych.

Ash jest przerażony zachodzącymi zmianami i jak Mojżesz na górze Horeb podaje 10 przykazań dla wolnego słowa, które mają ocalić świat liberałów; można powiedzieć, że jest zaangażowanym moralistą (czy też może aronowskim le spectateur engagé).

Zielonka stara się pozostać chłodnym analitykiem i wskazuje na problemy, które stanowią przyczynę takich lub innych reakcji europejskiego demos. Nie lekceważy bynajmniej wskazanych przez Asha zagrożeń (m.in. populizmem), ale też ich nie demonizuje. Uważa, że to $w$ dużej mierze elity liberalne zawiniły, nie potrafiąc rozwiązać problemów dotykających na co dzień zwykłych obywateli. Zatem nie można mieć do nich teraz pretensji, że w ten czy inny sposób wyrażają swoje niezadowolenie.

Wygląda na to, że we wszystkich państwach Europy zachodzą podobne procesy - niezależnie od tego, czy chodzi tu o obszar Europy Środkowej i Wschodniej, które przeszły transformację po komunizmie, czy też o obszar Europy Zachodniej, który wyzwolił się wcześniej z systemów autorytarnych (Hiszpania, Portugalia, Włochy, Grecja) - wydawałoby się - powinny być bardziej stabilne i odporne na tąpnięcia populistyczne. Dlatego zasadnie możemy zadać pytanie: co powoduje, że skoro miało być tak dobrze, jest tak źle?! Dlaczego prymusi transformacji popadają w zadyszkę i sukcesy, którymi się szczycili (i za które byli chwaleni), nie są bynajmniej przyjmowane z dobrodziejstwem inwentarza, a przechodzą „,cofkę transformacyjną"?

Innymi słowy, czy (wieczni) dysydenci, w których Tucker pokłada nadzieję, że wykażą się cnotą republikańskiej czujności w obronie uniwersalnych wartości mających być [właśnie] zagrożone krótkowzrocznym populizmem (Ash), potrafili uzyskaną wolność właściwie zagospodarować, budując trwałe i dobrze pomyślane instytucje, które służą wszystkim obywatelom oraz umożliwiają sprawne funkcjonowanie maszyny państwowej niezależnie, kto w ramach zmiany demokratycznej aktualnie sprawuje rządy?

\section{7.}

W tym kontekście chciałbym przywołać pewne prace, których autorzy zwracali uwagę na poważne problemy rysujące się na wzorcowym procesie transformacji 
systemowej, a które mogą stanowić przyczynę zauważalnego zwrotu krytycznego, co nie znaczy, że jedyną jego interpretacją jest interpretacja populistyczna. Mam na myśli opublikowaną pośmiertnie książkę Edmunda Mokrzyckiego Bilans niesentymentalny (2001) oraz wydaną pod jego współredakcją Utracona dynamikę? (Mokrzycki, Rychard, Zybertowicz). Przede wszystkim chciałbym zwrócić w tym kontekście uwagę na fundamentalne analizy instytucjonalne Antoniego Z. Kamińskiego, w których pojawia się problem odpowiedzialności, czy też raczej jej braku, elit za stan polskiej demokracji z punktu widzenia sprawności i funkcjonalności powołanych instytucji. Kamiński wraz z Joanną Kurczewską (2014) wysuwają tezę o nomadycznym charakterze elit, które zawłaszczają instytucje państwowe, aby realizować własne (lub partyjne) cele, nie dbając o to, by służyły one całemu społeczeństwu. Tym samym owe praktyki nomadycznego pasożytnictwa prowadzą do destabilizacji systemu i definiowania ad hoc celów instytucji, jak również permanentnej wymiany.

Intuicję tę podzielają nie tylko specjaliści (eksperci) od transformacji, lecz także byli dysydenci (przynajmniej niektórzy), by przywołać niedawno publikowany artykuł Czesława Bieleckiego, publicysty, więźnia politycznego czasów komunizmu, liberalnego polityka czasów transformacji, a na co dzień architekta, który w oparciu o kontakty z urzędnikami państwa ukuł bon mot, iż w Polsce sędziowie zachowują się jak urzędnicy, a urzędnicy jak sędziowie. Tym samym państwo nie służy obywatelowi, a podejmujący dotyczące go (nierzadko arbitralne) decyzje urzędnicy nie odpowiadają przed nikim, nawet nie przed Bogiem, ani przed Historią (Bielecki 2014, 2108a, 2018b). Inspiracją do napisania obu tekstów Bieleckiego (pierwszy jako próba diagnozy, drugi jako próba terapii) jest wydana niedawno książka Bartłomieja Sienkiewicza Państwo teoretyczne, byłego ministra spraw wewnętrznych w rządzie PO, a wcześniej analityka polskiej sceny politycznej, który jako student działał $\mathrm{w}$ ruchu pacyfistycznym (z obecnym ministrem spraw zagranicznych rządu PiS, Jackiem Czaputowiczem), a po 1989 roku współtworzył UOP i Ośrodek Studiów Wschodnich. Wspominam ową parantelę jako przykład myślenia ponad podziałami politycznymi i ideowymi ${ }^{4}$.

Kończąc: zasadnicze pytanie wiąże się z kwestią, czy dysydentom udało się stworzyć takie ramy instytucjonalne, które stanowią zabezpieczenie przed pokusą populizmu, nie tylko tym, że oferują obywatelom stabilne i dobrze funkcjonujące struktury państwa szanującego ich indywidualną wolność, lecz także gwarantujące poczucie bezpieczeństwa (w tym i socjalnego) wszystkim grupom społecznym? Jeśli nie, to dlaczego do tego doszło? Czyżby gen wolności i potrzeba życia w prawdzie pełniły jedynie funkcję negatywną, to znaczy uniemożliwiały (ostateczną) do-

4 W kontekście sporu o państwo teoretyczne ciekawą interpretację podwójnych wyborów z 2015 roku w kontekście sporu o transformację z 1989 roku przedstawia w świetle tradycji nie-Marksowskiego materializmu historycznego poznański badacz tradycji solidarności, Brzechczyn w artykule PolskadeKODowanie systemu (Brzechczyn 2016). 
minację przez opresyjne państwo totalitarne, jednak nie gwarantują już one skutecznego zagospodarowania instytucjonalnego i realizacji funkcji pozytywnej? Czy współczesne turbulencje liberalnych demokracji są jedynie powodowane czynnikami, przed którymi przestrzegają Tucker, Ash, czy też mają i inne przyczyny, w tym niedoskonałości instytucjonalne: wynik zaniedbań i dezercji elit w pierwszych latach transformacji, która trwa po dzień dzisiejszy? Wspomniana dezercja elit, biorąc pod uwagę ostatnie wydarzenia, by przywołać manifestacje zbuntowanych les giletes jaunes we Francji prowadzonej ku świetlanej przyszłości przez republikańskiego króla słońce, może być ważnym signum temporis (przestrogą) przed zapomnieniem o służebnej roli jaką (nierzadko skłócone) elity pełnią w stosunku do własnych obywateli, by przywołać gorące dyskusje i analizy we współczesnej literaturze światowej (Lilla; Mounk; Guilly 2014, 2018; Goodhart; Eatwell, Goodwin).

\section{BIBLIOGRAFIA}

Ash, Timothy Garton. Wolne słowo. Dziesięć zasad dla połaczonego świata. Przeł. Mieczysław Godyń, Filip Godyń. Kraków: IW Znak, 2018.

Bielecki, Czesław. Jest alternatywa. Każdy wie tyle ile wiedzieć chce. Szczególnie w polityce. Warszawa: Wydawnictwo Poltext, 2014.

Bielecki, Czesław. „Kto naprawdę rządzi Polską? Rzecz o polityce”. Rzeczpospolita 28 listopada 2018a.

Bielecki, Czesław. „Jak robić swoje?”. Rzeczpospolita 11 grudnia 2018b.

Brzechczyn, Krzysztof. "Polish Discussions on the Nature of Communism and Mechanisms of its Collapse: A Review Article”. East European Politics and Societies, 22: 4 (2008). S. 828-855.

Brzechczyn, Krzysztof. „Dziedzictwo Solidarności a przebieg transformacji systemowej w Polsce”. Solidarność i opozycja polityczna w Europie Środkowo-Wschodniej w latach 80. XX wieku. Wybrane zagadnienia. Red. J.R. Sielezin, M. Golińczak. Wrocław: Wyd. Uniwersytetu Wrocławskiego, 2012. S. 217-239.

Brzechczyn, Krzysztof. „Polska - deKODowanie systemu”. Arcana. Kultura - Historia - Polityka, 127-128 (2016). S. 34-48.

Bryant Chistopher G.A., Mokrzycki Edmund, red. Democracy, Civil Society and Pluralism. In Comparative Perspective: Poland, Great Britain and The Netherladns, Warszawa: IFiS Publishers, 1995.

Ciżewska, Elżbieta. Filozofia publiczna Solidarności. Solidarność 1980-1981 z perspektywy republikańskiej tradycji politycznej. Warszawa: Narodowe Centrum Kultury, 2010.

Ciżewska-Martyńska, Elżbieta. „Debata wokół republikanizmu ruchu społecznego „Solidarność”: Próba podsumowania z perspektywy filozofii politycznej”. Roczniki Filozoficzne, 2020 (w opracowaniu redakcyjnym).

Dunn, Elisabeth C. Prywatyzując Polskę. O bobofrutach, wielkim biznesie i restrukturyzacji pracy. Przeł. Przemysław Sadura. Wstęp D. Ost. Warszawa: Wydawnictwo Krytyki Politycznej, 2017.

Eatwell Roger, Goodwin Matthew. National Populism: The Revolt Against Liberal Democracy. Kingston: Penguin Books, 2018. 
Gdula Maciej, we współpracy z Katarzyną Dębską i Kamilem Trepką. Dobra zmiana w Miastku. Neoautorytaryzm w polskiej polityce z perspektywy matego miasta. Warszawa: Krytyka Polityczna, 2017.

Goodhart, David. The Road to Somewhere: The Populist Revolt and the Future of Politics. London: Hurst and Company, 2017.

Guilluy, Christophe. La France périphérique: Comment on a sacrifié les classes populaires. Paris: Editions Flammarion, 2014.

Guilluy, Chistophe. No Society: La fin de la classe moyenne occidentale. Paris: Editions Flammarion, 2018.

Hazony, Yoram. The Virtue of Nationalism. New York: Basic Books, 2018.

Hazony, Yoram. "Conservative Democracy: Liberal Principles have Brought Us to a Dead End". The First Things. Web. 03.01.2019. <https://www.firstthings.com/article/2019/01/conservative-democracy>

Kamiński Antoni Z., Kurczewska Joanna. „Przemiany instytucjonalne w Polsce, Elita politycznych nomadów". Dezercja elit. Konsolidacja ustroju politycznego w postkomunistycznej Polsce. Red. A.Z. Kamiński. Warszawa: ISP PAN, 2014. S. 81-105.

Kamiński, Antoni Z. „Polityczne wędrowanie. Jak może się tworzyć w Polsce ustrój demokratyczny?”. Dezercja elit. Konsolidacja ustroju politycznego w postkomunistycznej Polsce. Red. A.Z. Kamiński. Warszawa: ISP PAN, 2014. S. 75-79.

Krasnodębski, Zdzisław. „Republikańskie przesłanie programu Solidarności Walczącej”. Między solidaryzmem a niepodległością. Myśl polityczna Solidarności Walczącej. Red. K. Brzechczyn. Poznań-Warszawa: IPN, 2018. S. 11-17.

Krasnodębski, Zdzisław. Demokracja peryferii. Gdańsk: słowo/obraz terytoria, 2003.

di Lampedusa, Giuseppe Tomasi. Lampart. Przeł. Zofia Ernstowa. Warszawa: Państwowy Instytut Wydawniczy, 1963.

Lilla, Mark. Koniec liberalizmu jaki znamy. Requiem dla polityki tożsamości. Wstęp i przekład Łukasz Pawłowski. Warszawa: Fundacja Kultura Liberalna, 2018.

Mokrzycki, Edmund. Bilans niesentymentalny. Warszawa: Wydawnictwo IFiS PAN, 2001.

Mokrzycki Edmund, Rychard Andrzej, Zybertowicz Andrzej, red. Utracona dynamika? O niedojrzałości polskiej demokracji. Warszawa: IFiS PAN, 2001.

Mounk, Yascha. Lud kontra demokracja. Dlaczego nasza wolność jest w niebezpieczeństwie i jak ją ocalić. Przeł. Katarzyna Gucio. Warszawa: Fundacja Kultura Liberalna, 2019.

Ost, David. Solidarność a polityka antypolityki. Przeł. Sergiusz Kowalski. Gdańsk: ECS. 2014.

Ost, David. Klęska "Solidarności”. Gniew i polityka w postkomunistycznej Europie. Przeł. Hanna Jankowska. Warszawa: Warszawskie Wydawnictwo Literackie MUZA S.A, 2007.

Ost, David. "The Sham, and the Damage of «Living in Truth»". East European Politics and Societies and Cultures 32 (2018). S. 301-309.

Sienkiewicz, Barłłomiej. Państwo teoretyczne. Wydawnictwo Arbiror, 2018.

Staniszkis, Jadwiga. "Political Capitalism" in Poland. East European Politics and Societies 5 (1990). S. 127-141.

Staniszkis, Jadwiga. Postkomunizm. Próba opisu. Gdańsk: Słowo/obraz terytoria, 2001.

Stawrowski, Zbigniew. Solidarność znaczy więź. W kręgu myśli Józefa Tischnera i Jana Pawła II. Kraków: Instytut Myśli Józefa Tischnera, 2010. 
Śpiewak, Paweł. „Alexis de Tocqueville i Hannah Arendt o «Solidarności»”. Ideologie i obywatele. Warszawa: Biblioteka „Więzi", 1991.

Tucker, Aviezer. The Philosophy and Politics of Czech Dissidence from Patočka to Havel. Pittsburgh, PA: Pittsburgh University Press, 2000.

Tucker Aviezer, et al. "From Republican Virtue to Technology of Political Power: Three Episodes of Czech Nonpolitical Politics". Political Science Quarterly 115 (2000). S. 421-445 .

Tucker, Aviezer. The Legacies of Totalitarianism. A Theoretical Framework. New York: Cambridge University Press, 2015.

Wierzchosławski, Rafał. „Czy ingerencja wyklucza wolność? Wokół republikańskiego ujęcia «libertas»". Liberalizm u schyłku XX wieku. Red. J. Miklaszewska. Kraków: Wydawnictwo Meritum, 1999. S. 283- 317.

Wierzchosławski, Rafał. „Republikańska próba implementacji wolności jako braku dominacji”. Colloquia Communia 2 (2002). S. 367-384.

Wierzchosławski, Rafał. "The Role of Experts in the Condominium Model as Republican (Re-)Solution of Social, Economic, and Political Problems". Experts and Consensus in Social Science - Critical Perspectives from Economics, Sociology, Politics and Philosophy. Red. C. Martini. Heidelberg-New YorkDordrecht-London: M. Springer Verlag, 2014. S. 253-274.

Zielonka, Jan. Europa jako Imperium. Nowe spojrzenie na Unię Europejską. Warszawa: PISM, 2007.

Zielonka, Jan. Koniec Unii Europejskiej? Przeł. Elżbieta Gołębiowska. Warszawa: PISM, 2014.

Zielonka, Jan. Kontrrewolucja, Liberalna Europa w odwrocie. Przeł. Joanna Bednarek. Warszawa: PWN, 2018. 